\title{
Changes in the amounts of linoleic acid in the serum of patients with multiple sclerosis
}

\author{
R. W. R. BAKER, R. H. S. THOMPSON ${ }^{1}$, AND K. J. ZILKHA \\ From the Department of Chemical Pathology, Guy's Hospital Medical School, London, and the National \\ Hospital, Queen Square, London
}

In an earlier communication the results of a study of the fatty acid composition of total lipid extracts of control and multiple sclerosis sera were reported (Baker, Thompson, and Zilkha, 1964). These results were given as proportions, and the chief finding was a fall in the percentage of linoleic acid in the specimens from patients with multiple sclerosis, the magnitude of the change being linked with the activity of the disease process. Since a fall in the proportion of one acid might arise through an increase in the proportion of some other acid or acids, it is important to know not only the proportions but also the actual concentrations of the different fatty acids in the serum.

A further series of determinations has therefore been carried out in which the absolute levels (in $\mu \mathrm{moles} / \mathrm{ml}$. serum) of each of the major fatty acid components, both free and esterified, of the serum lipids have been estimated. For this purpose an internal standard was added to each measured sample of serum before extraction of the lipids. The standard used was either arachidic or linolenic acid, in the form of the free acid or its methyl ester, the addition in most cases being equivalent to $1.25 \mu$ moles acid $/ \mathrm{ml}$. serum. Gas-chromatographic analysis of the fatty acids in the extracted lipids was then carried out; the 'peak' shown by each acid was compared with the standard peak, thereby enabling the concentration of each of the serum fatty acids to be calculated.

By this means we have shown that among the major free and ester-linked fatty acid components of the serum lipids, linoleic acid alone declines in amount in patients with active multiple sclerosis, the other fatty acids remaining essentially unchanged in concentration.

Since the cholesteryl ester fraction of the serum lipids contains more linoleate than either the phospholipid or triglyceride fractions, measurements of the concentration of cholesteryl linoleate in the

'Present address: Courtauld Institute of Biochemistry, Middlesex Hospital Medical School, London, W.1. serum have already been undertaken and reported (Baker, Sanders, Thompson, and Zilkha, 1965); these measurements showed that the level of this fraction of the total serum linoleate is strikingly reduced in patients with active multiple sclerosis. Investigations of other fractions of the serum lipids are now in hand.

\section{SUBJECTS}

The subjects of the present study consisted of 20 controls and 26 patients with multiple sclerosis.

The cases of multiple sclerosis, 13 men and 13 women, aged 19-54 years, were all patients in the National Hospital, Queen Square, Guy's Hospital, or the Dunoran Home. As in our earlier work (Baker et al., 1964), the patients were classified into four grades at the time of drawing the blood sample, these grades being based on a clinical assessment of the activity of the disease as manifested by the development of new signs or symptoms or by the exacerbation or extension of already existing signs or symptoms during the preceding month. Since we had earlier shown that patients in grade I, i.e., showing no evidence of recent deterioration, show no deviation from normal in the percentage of linoleic acid in the serum lipids, the patients included in the present study were all taken from grades II, III, and IV, and showed clinical evidence of slight, moderate, and extensive recent deterioration respectively.

The controls consisted of 13 healthy subjects, six men and seven women, aged 19 to 53 years, and seven 'neurological controls', i.e., in-patients suffering from nervous disorders other than primary demyelinating diseases; they comprised two men and five women, whose ages ranged from 13 to 61 years.

Blood was drawn from each subject from the antecubital vein after an overnight fast. The subsequent analyses were carried out 'blind', the analyst being unaware of the identity of the specimens.

\section{ANALYTICAL METHODS}

The compounds used as standards were either arachidic acid (Mann Research Laboratories), $99 \%$ pure by thinlayer chromatography, or methyl linolenate prepared from linolenic acid (B. Newton Maire, Ltd.), $80-85 \%$ 
pure. The purity of these standards was checked by gas chromatography.

For extraction of lipids the method of Folch, Lees, and Sloane Stanley (1957) was used on a small scale. To $6.85 \mathrm{ml}$. chloroform-methanol $(2: 1 \mathrm{v} / \mathrm{v})$ was added 0.5 $\mathrm{ml}$. of the standard solution ( $1 \mu \mathrm{mole} / \mathrm{ml}$. chloroform) of either arachidic acid or methyl linolenate. After the addition of $0.25 \mathrm{ml}$. methanol and $0.4 \mathrm{ml}$. serum the mixture was shaken vigorously; $1.6 \mathrm{ml}$. $0.1 \mathrm{M}$ aqueous $\mathrm{KCl}$ was then added, and after several inversions the mixture was centrifuged and the upper layer discarded.

Most of the lower layer $(5 \mathrm{ml}$.) was transferred to a fresh tube for evaporation at $50^{\circ} \mathrm{C}$. in a stream of $\mathrm{N}_{2}$, and the residue, suspended in $3 \mathrm{ml}$. ethanol, was hydrolysed at $36^{\circ}$ for $30 \mathrm{~min}$. after adding $0.3 \mathrm{ml} .10 \mathrm{~N}$ aqueous KOH.

Isolation of the fatty acids as their methyl esters and their separation by gas chromatography on 6-foot polyester columns were exactly as described earlier (Baker et al., 1964). For chromatography, $1 \mu \mathrm{l}$. of a solution of the mixed methyl esters derived from the serum sample in $20 \mu$ l. diethyl ether was used with attenuation $\times 20$ for the Perkin-Elmer model 800 gas chromatograph.

The area of each fatty acid peak on the chromatogram was measured by triangulation. As identical molar amounts of the methyl esters of different fatty acids do not give identical peak areas, the area measured for each peak in the serum chromatogram was converted to standard relative molar area by multiplying by a constant characteristic for the particular acid. These correction constants were determined by submitting mixtures of different fatty acids of known purity to the same procedure as used for the sera; the molar constants, relative to linolenic acid taken as the arbitrary standard, i.e., the reciprocal of the ratios of the peak areas, of equimolar amounts of the two acids are as listed below:

$\begin{array}{llllll}\text { Myristic } & 1.231 & \text { Stearic } & 0.810 & \text { Linolenic } & 1.000 \\ \text { Palmitic } & 0.980 & \text { Oleic } & 0.846 & \text { Arachidic } & 0.765 \\ \text { Palmitoleic } & 0.980 & \text { Linoleic } 1.053 & \text { Arachidonic } & 1.325\end{array}$

These constants therefore apply as corrections for the method used as a whole, as distinct from the constants proposed by Ettre and Kabot (1963), which apply to the chromatographic procedure only.

\section{RESULTS}

REPRODUCIBILITY OF THE ANALYTICAL METHODS In preliminary experiments with three different sera it was shown that duplicate analyses of the methyl esters obtained from a given sample of serum gave values for each of the major acids that differed by less than $0.1 \mu \mathrm{mole} / \mathrm{ml}$. serum from the mean for the two determinations.

When two samples from the same serum were analysed, using arachidic acid as internal standard for one and methyl linolenate for the other, the reproducibility attained was within $0 \cdot 2 \mu \mathrm{mole} / \mathrm{ml}$. serum of the mean value in the case of each of the major acids.

SERUM LEVELS The levels of the eight most abundant fatty acids present in the serum of the control subjects are shown in Table I as means ( $\mu$ moles $/ \mathrm{ml}$.$) ,$ with standard errors of the means. The values for acids listed as 'others' include the various minor components (usually 10), no one of which was present in amounts exceeding $0.075 \mu$ moles $/ \mathrm{ml}$. Since the means in the six healthy men were indistinguishable, for each of the acids, from those found in the two male neurological controls, these two groups have been combined and are considered as a single group of eight control males.

It will be seen that the group of seven healthy women gave mean values for myristic, palmitic, palmitoleic, and oleic acids which are significantly lower than the means for these acids in the men, whereas the values for linoleic and the other acids were essentially the same for both sexes. Furthermore, the five female neurological controls showed values for palmitoleic and oleic acids which were

TABLE I

MEAN FATTY ACID LEVELS IN SERUM FROM CONTROL SUBJECTS

( $\mu$ MOLES/ML. SERUM, WITH S.E.M.)

\begin{tabular}{|c|c|c|c|c|c|}
\hline \multirow[b]{2}{*}{ Acid } & \multirow[b]{2}{*}{ Males (8) } & \multirow[b]{2}{*}{$\begin{array}{l}\text { Healthy } \\
\text { Females (7) }\end{array}$} & \multirow[b]{2}{*}{$\begin{array}{l}\text { Female } \\
\text { Neurological } \\
\text { Control (5) }\end{array}$} & \multicolumn{2}{|c|}{ Significance $(P)$} \\
\hline & & & & $\begin{array}{l}\text { Males } v . \\
\text { Healthy } \\
\text { Females }\end{array}$ & $\begin{array}{l}\text { Healthy Females } \\
\text { v. Female Neurological } \\
\text { Control }\end{array}$ \\
\hline Myristic & $0.31(0.04)$ & $0.14(0.02)$ & $0.22(0.03)$ & $<0.01$ & n.s. \\
\hline Palmitic & $3.43(0.29)$ & $2.40(0.11)$ & $2.83(0 \cdot 11)$ & $<0.02$ & n.s. \\
\hline Palmitoleic & $0.73(0.06)$ & $0.39(0.03)$ & $0.77(0.09)$ & $<<0.01$ & $<<0.01$ \\
\hline Stearic & $0.98(0.09)$ & $0.78(0.11)$ & $0.85(0.04)$ & n.s. & n.s. \\
\hline Oleic & $3.95(0.38)$ & $2 \cdot 58(0 \cdot 17)$ & $3.41(0.20)$ & $<0.01$ & $<0.02$ \\
\hline Linoleic & $3.81(0.13)$ & $3.45(0.16)$ & $3.78(0 \cdot 16)$ & n.s. & n.s. \\
\hline Eicosatrienoic & $0.18(0.02)$ & $0.16(0.01)$ & $0.21(0.02)$ & n.s. & n.s. \\
\hline Arachidonic & $0.90(0.11)$ & $0.84(0.06)$ & $0.91(0.04)$ & n.s. & n.s. \\
\hline Others & $0.62(0.10)$ & $0.67(0.11)$ & $0.44(0 \cdot 10)$ & n.s. & n.s. \\
\hline Total & $14.91(0.93)$ & $11.41(0.48)$ & $13.42(0.44)$ & $<0.01$ & $<0.02$ \\
\hline
\end{tabular}

n.s. = not significant 
TABLE II

MEAN FATTY ACID LEVELS IN SERUM FROM PATIENTS WITH MULTIPLE SCLEROSIS, GRADED ACCORDING TO ACTIVITY OF THE DISEASE, AND FROM CONTROL SUBJECTS (HEALTHY AND NEUROLOGICAL CONTROLS GROUPED TOGETHER)

( $\mu$ MOLES/ML. SERUM, WITH S.E.M.)

\begin{tabular}{|c|c|c|c|c|}
\hline \multirow[b]{2}{*}{ Acid } & \multirow{2}{*}{$\begin{array}{l}\text { All Control Subjects } \\
\text { (Healthy and } \\
\text { Neurological Controls) } \\
20 \\
(8 \text { males }) \\
(12 \text { females })\end{array}$} & \multicolumn{3}{|c|}{ Multiple Sclerosis Patients } \\
\hline & & $\begin{array}{l}\text { Grade II } \\
7 \\
(2 \text { males }) \\
(5 \text { females })\end{array}$ & $\begin{array}{l}\text { Grade III } \\
8 \\
(5 \text { males }) \\
(3 \text { females })\end{array}$ & $\begin{array}{l}\text { Grade IV } \\
I 1 \\
(6 \text { males }) \\
(5 \text { females })\end{array}$ \\
\hline $\begin{array}{l}\text { Myristic } \\
\text { Palmitic } \\
\text { Palmitoleic } \\
\text { Stearic } \\
\text { Oleic } \\
\text { Linoleic } \\
\text { Eicosatrienoic } \\
\text { Arachidonic } \\
\text { Others } \\
\text { Total }\end{array}$ & $\begin{array}{c}0.23(0.02) \\
2.92(0.13) \\
0.62(0.05) \\
0.88(0.04) \\
3.34(0.31) \\
3.68(0.09) \\
0.18(0.01) \\
0.88(0.05) \\
0.58(0.06) \\
13.31(0.34)\end{array}$ & $\begin{array}{c}0.26(0.03) \\
2.78(0.13)^{1} \\
0.72(0.09) \\
0.99(0.11) \\
3.04(0.22)^{1} \\
3.74(0.18)^{1} \\
0.22(0.03) \\
0.97(0.09) \\
0.24(0.09) \\
12.96(0.51)^{1}\end{array}$ & $\begin{array}{r}0.23(0.06) \\
2.71(0.29) \\
0.60(0.07) \\
0.71(0.08) \\
2.95(0.30) \\
3.06(0.20) \\
0.15(0.02) \\
0.90(0.14) \\
0.40(0.07) \\
11.71(1.12)\end{array}$ & $\begin{array}{c}0.20(0.02) \\
2.96(0.15) \\
0.79(0.08) \\
0.77(0.05) \\
3.22(0.19) \\
2.79(0.16) \\
0.20(0.03) \\
0.92(0.10) \\
0.70(0.22)^{2} \\
12.55(0.82)^{2}\end{array}$ \\
\hline
\end{tabular}

${ }^{1}$ Means for six subjects

${ }^{2}$ Means for 10 subjects

significantly higher than in the case of the healthy female controls, and which tended towards the pattern found in men. It should be pointed out however that the mean age ( 27 years) of the group of healthy women was appreciably less than the mean age of the female neurological controls (41 years); the mean age of the male group was 34 years. These divergencies between these groups of control subjects are in accord with the finding by Böhle, Böttcher, Piekarski, and Biegler (1956) of a lower mean for the total serum fatty acids in young women, but not for women past the menopause, as compared with men.

The serum levels of stearic, linoleic, eicosatrienoic, and arachidonic acids appeared to be essentially the same for the healthy and for the neurological controls and to be independent of sex. This permitted these three control groups to be combined to give means for each of these acids, representing normality, which appear in Table II together with results from multiple sclerosis patients subdivided according to activity of the disease as already defined (Baker et al., 1964). In Table II, values for the other acids are also shown under these headings, since the two sexes are represented in all groups, and since no differences between the means for the two sexes could be shown for the multiple sclerosis patients in the small groups involved. Further, when male multiple sclerosis patients are compared with male control subjects, or female patients with female controls, no differences of any significance were seen in the case of the acids which vary with sex, i.e., myristic, palmitic, palmitoleic, and oleic.

Table II reveals the fact that only in the case of linoleic acid are differences of real significance to be found between the controls and patients with mul- tiple sclerosis, and then only in those patients showing evidence of recent activity of the disease process. Thus, although the mean linoleic acid level in grade II patients, i.e., those with minimal signs of recent or continuing pathological activity, does not differ from that in the control subjects, the levels in grades III and IV are significantly lower $(\mathrm{P}<\mathbf{0 . 0 1})$. The mean level of acids listed as 'others' in the grade II patients is considerably lower than in the control group. However, as these acids comprise a number of very minor components, no significance can be attached to this difference in the means of their total, and it will further be noted that in grades III and IV the mean level approximates to that for the controls.

\section{DISCUSSION}

In general, the substance used as an internal standard in a quantitative estimation must be of such physical form and chemical nature as to be capable of preparation as a stable standard solution, and preferably should possess chemical properties resembling as closely as possible those of the substances being determined. Further, its peak on the final gas chromatogram must occupy a position where the chromatographic trace of the test material runs along or near to the base-line, thus dispensing with or minimizing the need for correction. On these criteria both methyl linolenate and arachidic acid are acceptable as internal standards.

In preliminary experiments both standards were added to the serum, with closely concordant results. In further trials arachidic acid was added to the serum initially, while methyl linolenate was added to the extracted methyl esters immediately before 
chromatography; by this means it was shown that recoveries were satisfactory and in fact practically quantitative.

The mean value obtained by us for the total serum fatty acid level in control subjects, 13.31 $\mu$ moles $/ \mathrm{ml}$. (Table II), is in reasonable agreement with the published figures given by other workers. Only a few reports are available of determinations of the levels of individual fatty acids in normal serum, but Schrade, Böhle, Biegler, Meder, and Teicke (1960), using a gas chromatographic technique, have reported a value for total serum linoleate of 3.41 $\mu$ moles $/ \mathrm{ml}$., which, again, is in good agreement with our figure of $3.68 \pm 0.09 \mu \mathrm{moles} / \mathrm{ml}$. Percentages $(w / w)$ of linoleic acid in the serum fatty acids are given as 25.99 (Martinelli, Turchette, and Sechi, 1960), 23.98 (Schrade et al., 1960), and 25.6 (Baker et al., 1964); calculated as moles/100 moles total fatty acids these values become $25 \cdot 6,23 \cdot 6$, and $25 \cdot 2$, compared with $27.6 \%$ in the present work (Table II).

It has already been reported that the percentage of linoleic acid in the serum fatty acids, and also the level of cholesteryl linoleate in the serum, is reduced in patients with active multiple sclerosis, although each is unaffected in the inactive stages of the disease (Baker et al., 1965). The present work shows that the absolute level of total serum linoleate is also markedly reduced in patients in the active phases of the disease, the patients in grade II again showing levels that do not differ significantly from the control range. It is of interest that among the various serum fatty acids which we have measured linoleic acid is the only one in which we have been able to demonstrate a significant change.

\section{SUMMARY}

The absolute levels of each of the major fatty acid components, both free and esterified, of the serum lipids have been estimated in specimens from 26 patients with multiple sclerosis and 20 control subjects, by a gas chromatographic method using an internal standard.

A significant reduction in the level of linoleate in the serum is found in patients showing evidence of recent deterioration. In the inactive phases of the disease the levels of linoleate are within the normal range.

None of the other fatty acids which we have measured showed any significant change from normal.

We wish to thank the various physicians in charge of the patients for their kind cooperation in this work. Our thanks are also due to the Multiple Sclerosis Society for a grant to assist this work, and to Miss P. Hawkes for her skilled technical help.

\section{REFERENCES}

Baker, R. W. R., Thompson, R. H. S., and Zilkha, K. J. (1964). Serum fatty acids in multiple sclerosis. J. Neurol. Neurosurg. Psychiat., 27, 408-414.

—, Sanders, H., Thompson, R. H. S., and Zilkha, K. J. (1965). Serum cholesterol linoleate levels in multiple sclerosis. Ibid., 28, 212-217.

Böhle, E., Böttcher, K., Piekarski, H. G., and Biegler, R. (1956). Die Serumlipoproteide und ihre Beziehungen zu den Proteinund Lipidfraktionen des Blutes unter Berücksichtigung von Alter und Geschlecht. Disch. Arch. klin. Med., 203, 29-51.

Ettre, L. S., and Kabot, F. J. (1963). Relative response of fatty acid methyl esters on the flame ionization detector. J. Chromatogr., 11, 114-116.

Folch, J., Lees, M., and Sloane Stanley, G. H. (1957). A simple method for the isolation and purification of total lipides from animal tissues. J. biol. Chem., 226, 497-509.

Martinelli, M., Turchette, E., and Sechi, A. M. (1960). Prime osservazioni sugli acidi grassi dei lipidi e delle frazioni lipidiche di sangue umano normale mediante la cromatografia in fase gassosa. Boll. Soc. ital. biol. sper., 36, 1700-1703.

Schrade, W., Böhle, E., Biegler, R., Meder, V., and Teicke, R. (1960). Gaschromatographische Untersuchungen der Serumfettsäuren des Menschen. Klin. Wschr., 38, 126-134. 